\title{
Gagal Ginjal Kronik Hemodialisis dengan Kadar Eritropoietin dan Hemoglobin Normal: Laporan Kasus
}

\author{
Tulus Amudi, ${ }^{1}$ Stella Palar $^{2}$
}

\author{
${ }^{1}$ Program Pendidikan Dokter Spesialis Bagian Ilmu Penyakit Dalam Fakultas Kedokteran \\ Universitas Sam Ratulangi, Manado, Sulawesi Utara, Indonesia \\ ${ }^{2}$ Bagian Ilmu Penyakit Dalam Fakultas Kedokteran Universitas Sam Ratulangi - RSUP Prof. \\ Dr. R. D. Kandou, Manado, Sulawesi Utara, Indonesia \\ Email: tulusamudi@gmail.com
}

\begin{abstract}
Generally, chronic kidney disease (CKD) is associated with anemia due to decrease of erythropoietin that plays an important role in erythropoiesis. We reported a patient, 61-year-old male, suffered from chronic hemodialysis kidney disease with coinfection of viral hepatitis $\mathrm{C}$, albeit, had normal hemoglobin and erythropoietin levels. The patient was diagnosed as CKD in March 2014 with laboratory results, as follows: hemoglobin (Hb) $9.9 \mathrm{~g} / \mathrm{dl}$; ureum $223 \mathrm{mg} / \mathrm{dl}$; creatinine $7.5 \mathrm{mg} / \mathrm{dl}$, and was confirmed with ultrasonography. The patient underwent hemodialysis and was treated with erythropoiesis stimulating agent (ESA) for the first time in April 2014. The last ESA was given in June 2015 and the laboratory results were serum iron $61 \mu \mathrm{g} / \mathrm{dl}$, total iron binding capacity (TIBC) $173 \mu \mathrm{g} / \mathrm{dl}$, ferritin $1431 \mathrm{ng} / \mathrm{ml}$, and the qualitative anti $\mathrm{HCV}$ test was reactive. Afterwards, the patient was not treated with ESA anymore since his $\mathrm{Hb}$ level was normal without ESA or blood transfusion. Moreover, the erythropoietin (EPO) level was tested in December 2018 resulted within normal level. Until now, the patient is still undergoing hemodialysis without ESA or transfusion. This is a rare condition, and there is still no certain pathophysiology to explain. It is assumed that the mechanism is related to hepatitis $\mathrm{C}$ infection that stimulates the hepatocyte regeneration, therefore, the cells produce endogen erythropoietin resulting in increased $\mathrm{Hb}$ level.
\end{abstract}

Keywords: chronic kidney disease (CKD), erythropoietin and hemoglobin level

\begin{abstract}
Abstrak: Umumnya penyakit ginjal kronik (PGK) disertai dengan anemia akibat penurunan eritropoietin yang berperan penting dalam proses eritropoiesis. Kami melaporkan kasus seorang lakilaki 61 tahun dengan PGK hemodialisis disertai ko-infeksi hepatitis C namun dengan kadar hemoglobin dan eritropoietin normal. Pasien dinyatakan PGK sejak Maret 2014 dengan kadar hemoglobin $(\mathrm{Hb})$ 9,9 $\mathrm{g} / \mathrm{dL}$; ureum $223 \mathrm{mg} / \mathrm{dl}$; kreatinin 7,5 mg/dl, dan didukung oleh hasil ultrasonografi. Pasien diberikan hemodialisis dan terapi ESA pertama kali pada bulan April 2014. Terapi ESA terakhir diberikan pada bulan Juni 2015 dengan hasil serum iron $61 \mu \mathrm{g} / \mathrm{dl}$, total iron binding capacity (TIBC) $173 \mu \mathrm{g} / \mathrm{dl}$, feritin $1431 \mathrm{ng} / \mathrm{ml}$, dan anti HCV kualitatif reaktif, Setelah itu pasien tidak mendapat terapi ESA lagi karena pada pemeriksaan laboratorium ditemukan kadar hemoglobin normal tanpa terapi ESA atau transfusi darah. Pemeriksaan kadar eritropoietin (EPO) pada bulan Desember 2018 mendapatkan hasil $16 \mathrm{mIU} / \mathrm{ml}$ (nilai normal 2,6-18,5 mIU/ml). Hingga saat ini pasien masih rutin menjalani hemodialisis dan tidak pernah mendapat terapi ESA atau transfusi darah. Keadaan tersebut jarang ditemukan, dan tidak ada patofisologi yang pasti untuk menjelaskan penyebab keadaan tersebut. Mekanisme keadaan ini dikaitkan dengan infeksi hepatitis $\mathrm{C}$ yang merangsang regenerasi hepatosit, sehingga sel-sel tersebut menghasilkan hormon ertiropoietin endogen, dengan hasil akhir ialah peningkatan hemoglobin.
\end{abstract}

Kata kunci: penyakit ginjal kronik (PGK), kadar eritropoietin dan hemoglobin 


\section{PENDAHULUAN}

Penyakit ginjal kronik merupakan suatu proses patofisologik dengan etiologi yang beragam, mengakibatkan penurunan fungsi ginjal yang progresif, dan umumnya berakhir dengan gagal ginjal. Fungsi ginjal di dalam tubuh memiliki peranan penting seperti pengaturan metabolisme tubuh, endokrin, dan kontribusinya dalam pembentukan sel darah merah yang dikenal sebagai eritropoiesis. Eritropoiesis yang dihasilkan oleh ginjal akan terganggu pada penyakit gagal ginjal kronik (GGK), yang berakibat terjadinya gangguan pembentukan sel darah merah. ${ }^{1}$

Anemia merupakan salah satu komplikasi pada pasien dengan penyakit ginjal kronik (PGK). Penyebab anemia pada pasien PGK sangat multifaktorial di antaranya ialah pemendekan umur eritrosit yang disebabkan karena uremia, defisiensi zat besi, fibrosis sumsum tulang, defisiensi kadar eritropoietin, dan hiperparatiroidisme. ${ }^{1}$

Umumnya pasien dengan PGK yang menjalani terapi pengganti ginjal (hemodialisis) menggunakan terapi stimulan eritropoietin (erythropoietin stimulating agent, ESA). Hal ini dimaksudkan untuk merangsang produksi hormon eritropoietin sehingga produksi hemoglobin berlangsung dengan baik dan dapat mencegah terjadinya anemia pada pasien PGK. Terapi ESA diberikan untuk mempertahankan kadar hemoglobin pasien PGK. ${ }^{2}$ Pada umumnya pasien diberikan terapi ESA bila kadar hemoglobin di bawah $10 \mathrm{~g} / \mathrm{dl}$ karena keadaan anemia kronik sangat berbahaya bagi pasien PGK. ${ }^{3}$

Pada beberapa kondisi ditemukan kadar hemoglobin yang normal pada pasien PGK yang menjalani terapi dialisis dengan status kadar hormon eritropoietin yang normal walaupun tanpa pemberian terapi ESA sebelumnya. Kondisi tersebut dapat ditemukan antara lain pada pasien PGK dengan koinfeksi hepatitis C., ${ }^{3,4}$

Kami melaporkan sebuah kasus seorang laki-laki berusia 61 tahun dengan PGK dan ko-infeksi hepatitis $\mathrm{C}$ yang menjalani terapi hemodialisis di RSUP Prof. Dr. Dr. R. D. Kandou Manado.

\section{LAPORAN KASUS}

Seorang laki-laki berusia 61 tahun, suku Minahasa, dinyatakan PGK pada tahun 2014. Pasien dianjurkan pertama kali untuk menggunakan terapi pengganti ginjal (hemodialisis) pada bulan Maret 2014 di Unit Hemodialisa RSUP Prof. Dr. Dr. R. D. Kandou Manado. Awalnya pasien dinyatakan menderita penyakit ginjal, saat pasien masuk ke rumah sakit dengan keluhan sesak nafas yang dirasakan terus menerus. Pasien memiliki riwayat hipertensi sekitar 5 tahun sebelumnya yang tidak terkontrol dengan terapi anti hipertensi. Riwayat asam urat, diabetes melitus, jantung, paru, dan penyakit hati disangkal. Riwayat kosnumsi obat penahan nyeri disangkal. Pada riwayat penyakit keluarga atau anggota keluarga tidak didapatkan yang menderita keluhan yang sama. Riwayat kebiasaan merokok dan alkohol disangkal.

Pada pemeriksaan laboratorium tanggal 17 Maret 2014 didapatkan hemoglobin (Hb)

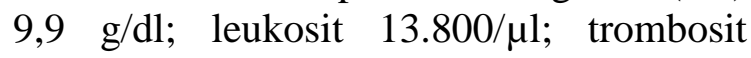

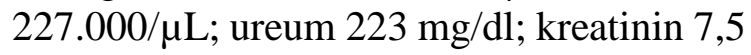
$\mathrm{mg} / \mathrm{dl}$; natrium $130 \mathrm{~m} / \mathrm{mmol}$; kalium 5,0 $\mathrm{mmol} / \mathrm{l}$; gula darah sewaktu $125 \mathrm{mg} / \mathrm{dl}$. anti HCV kualitatif non reaktif; HbsAg Elisa non reaktif; dan anti HIV Elisa non reaktif. Hasil elektrokardiografi mendapatkan irama sinus normal, dengan denyut jantung $75 \mathrm{x} /$ menit. Pada pemeriksaan foto toraks tidak didapatkan kelainan. Pemeriksaan ultrasonografi (USG) pada tanggal 14 Maret 2014 mendapatkan hasil ukuran kedua ginjal yang sudah mengecil, batas korteks dan medula yang menipis, dengan kesan PGK (chronic kidney disease/CKD) pada kedua ginjal, dan tidak tampak kelainan pada organ lain. Pasien mendapatkan terapi anti hipertensi amlodipin $10 \mathrm{mg}$ tiap 24 jam pada pagi hari dan telmisartan $80 \mathrm{mg}$ tiap 24 jam pada malam hari, dan diindikasikan untuk menjalani terapi pengganti ginjal (hemodialisis).

Pasien mendapat terapi ESA pertama kali pada bulan April 2014. Hasil laboratorium saat pasien mendapat terapi ESA ialah sebagai berikut: leukosit $13.000 / \mu \mathrm{L}$; eritrosit $3.01 \times 10^{6} / \mu \mathrm{L} ; \mathrm{Hb} 9.4 \mathrm{~g} / \mathrm{dL} ; \mathrm{MCV}$ 87,9 fL; MCH 31,2 pg; MCHC 35,5 g/dL Ht 26,8\%; trombosit $317.000 / \mu \mathrm{L}$; ureum 138 
$\mathrm{mg} / \mathrm{dL}$; dan kreatinin $6,2 \mathrm{mg} / \mathrm{dL}$. Pemeriksaan laboratorium pada bulan Juni 2015 mendapatkan hasil serum iron $61 \mu \mathrm{g} / \mathrm{dl}$, total iron binding capacity (TIBC) 173 $\mu \mathrm{g} / \mathrm{dl}$, feritin $1431 \mathrm{ng} / \mathrm{ml}$, fosfor $5,7 \mathrm{mg} / \mathrm{dl}$, calcium $8.51 \mathrm{mg} / \mathrm{dl}$, magnesium $2.56 \mathrm{mg} / \mathrm{dl}$, anti HCV kualitatif reaktif, sedangkan HbsAg dan anti HIV non-reaktif sehingga pasien dinyatakan terinfeksi hepatitis $\mathrm{C}$ pada bulan Juni 2015. Menurut keterangan pasien, pasien mendapat terapi ESA terakhir pada bulan Juni 2015. Setelah itu pasien tidak mendapat terapi ESA karena pada pemeriksaan laboratorium ditemukan kadar hemoglobin yang normal tanpa terapi ESA dan tanpa transfusi darah.

Hasil laboratorium kontrol pada tanggal 11 Januari 2018 mendapatkan kadar hemoglobin $14,8 \mathrm{~g} / \mathrm{dl}$, hematokrit $44,8 \%$, feritin $1228 \mathrm{ng} / \mathrm{ml}$, SI $67 \mu \mathrm{g} / \mathrm{dl}$, TIBC $252 \mu \mathrm{g} / \mathrm{dl}$, ureum $88 \mathrm{mg} / \mathrm{dl}$, keatinin $8,9 \mathrm{mg} / \mathrm{dl}$, asam urat $6,3 \mathrm{mg} / \mathrm{dl}$, gula darah puasa $82 \mathrm{mg} / \mathrm{dl}$. Pasien direncanakan untuk pemeriksaan kadar eritropoietin, namun sebelumnya dilakukan permeriksan laboratorium kontrol pada tanggal 15 November 2018 dan didapatkan hasil leukosit $7.800 / \mu \mathrm{L}$; eritrosit 4,61 x $10^{6} / \mu \mathrm{L} ; \mathrm{Hb} 15,5 \mathrm{~g} / \mathrm{dL} ; \mathrm{Ht} 45,4 \%$; MCV 98,5 fL; MCH 33,6 pg; MCHC 34,1 g/; dan trombosit $317.000 / \mu \mathrm{L}$. Kemudian pasien dilakukan pemeriksaan kadar eritropoietin (EPO) pada bulan Desember 2018 dengan metode pemeriksaan immunometric assay (Siemens Immulate 2000) dan didapatkan hasil $16 \mathrm{mIU} / \mathrm{ml}$ (nilai normal 2,6-18,5 mIU/ $\mathrm{ml}$ ). Hingga saat ini pasien masih rutin menjalani hemodialisis dan tidak pernah mendapat terapi ESA atau transfusi darah

Pemeriksaan USG abdomen dan ginjal pada tanggal 12 Maret 2019 mendapatkan hasil gambaran organ hati normal (ukuran normal, tepi tajam, permukaan rata, ekoparenkim hepar baik, sistem biliar baik, vena porta dan vena hepatika normal, dan tidak tampak gambaran nodul hepar), sedangkan untuk gambaran ginjal kanan dan kiri didapatkan ukuran ginjal yang mengecil, tepi tidak rata, intensitas ekoparenkim ginjal yang meningkat, batas korteks dengan medula yang tidak tegas, dan tidak ditemukan gambaran batu ataupun nodul pada kedua ginjal. Untuk organ lain seperti lien, pankreas, ureter kanan dan kiri, dan kandung kemih tidak ditemukan kelainan. Dari hasil USG disimpulkan kesan PGK bilateral.

\section{BAHASAN}

Penyakit ginjal kronik (PGK) mengakibatkan penurunan fungsi ginjal yang progresif, dan umumnya berakhir dengan gagal ginjal yaitu suatu keadaan klinis yang ditandai dengan penurunan fungsi ginjal yang ireversibel. Pravelensi kasus PGK di negara berkembang semakin meningkat. Khususnya di negara berkembang angka kejadian PGK diperkirakan sekitar 40-60 kasus per juta penduduk. Etiologi PGK sangat bervariasi, dan penyebab tersering ialah hipertensi, diabetes melitus, glomerulonefritis, obstruksi saluran kemih, dan infeksi saluran kemih. ${ }^{1}$ Pada kasus ini penyebab PGK ialah hipertensi kronis yang tidak terkontrol, berdasarkan riwayat pasien yang telah menyandang hipertensi sejak 5 tahun sebelum ditegakkan diagnosis PGK.

Ginjal memiliki peranan penting seperti pengaturan metabolisme tubuh, endokrin, dan eritropoiesis. Eritropoiesis berperan dalam pematangan sel darah merah. Eritropoiesis yang dihasilkan oleh ginjal akan terganggu pada PGK. Patogenesis anemia pada PGK ialah multifaktorial. Kadar ureum yang tinggi menyebabkan pemendekan umur eritrosit, kekurangan hormon eritropoietin menyebabkan terganggunya proses hematopoiesis, hiperparatiroid, fibrosis sumsum tulang, defisiensi zat besi, ataupun perdarahan pada saluran cerna yang sering dialami pada pasien dengan kadar ureum yang tinggi. ${ }^{1,2}$

Keadaan anemia pada pasien PGK umumnya disebabkan karena kekurangan kadar hormon eritropoietin, sehingga untuk pencegahan terjadinya anemia kronik pada pasien PGK ialah dengan pemberian terapi ESA. Hal ini bertujuan untuk mempertahankan kadar hemoglobin pasien. ${ }^{2}$ Terdapat beberapa kasus pasien dengan PGK yang menjalani hemodialisis terkadang ditemukan peningkatan kadar hemoglobin (eritrositosis). Hal ini biasa dijumpai pada 
pasien dengan kista ginjal, renal cell carcinoma $(R C C)$, pasien PGK dengan obstructive sleep apnea syndrome (OSA), hepatitis $\mathrm{C}$ kronik, dan pasca transplantasi renal. Eritropoietin umumnya dibentuk dari ginjal, tetapi hati juga dapat memroduksi eritropoietin dalam jumlah kecil. ${ }^{3}$

Pasien yang rutin menjalani hemodialisis sering dikaitkan dengan infeksi hepatitis $\mathrm{C}$ mengingat proses penularan infeksi hepatitis $\mathrm{C}$ ialah dengan penetrasi langsung virus tersebut ke dalam membran sel dan menyebar ke sel darah. Pada pasien PGK yang harus menjalani hemodialisis secara rutin akan berisiko terinfeksi heaptitis $\mathrm{C}$ lebih tinggi. Beberapa proses transmisi infeksi Hepatitis C (HCV) pada pasien PGK di antaranya ialah penggunaan alat hemodialisis atau dialisat yang bergantian dengan pasien lain, transfusi darah berulang, dan penggunaan jarum yang sudah terpapar oleh virus hepatitis $C$ (infeksi nosokomial). Caramello et $\mathrm{al}^{5}$ menyatakan bahwa penggunaan dialisat yang berulang berhubungan dengan transmisi HCV. Pada pasien ini diketahui terinfeksi hepatitis $\mathrm{C}$ pada tahun 2015 yaitu setelah pasien menjalani hemodialisis selama 1 tahun sebelumnya.

Pasien PGK terkadang mengalami peningkatan hemoglobin ataupun kadar hemoglobin normal. Hal ini dipengaruhi oleh kadar hormon eritropoietin yang normal pada pasien PGK tersebeut. Kadar eritropoietin dalam tubuh pada pasien PGK seharusnya akan mengalami penurunan seiring penurunan fungsi ginjal namun terdapat beberapa kasus dimana kadar eritropoitin tidak mengalami penurunan, sehingga menyebabkan kadar hemoglobin pasien tersebut tetap normal. Selain itu, kadar hemoglobin yang normal pada PGK dapat juga disebabkan karena hipoksemia kronik yang merangsang pembentukan eritropoietin. Seperti halnya pada kista ginjal yang menjadi salah satu penyebab terjadinya peningkatan kadar eritropoietin, karena sel-sel yang terdapat pada kista tersebut mampu secara mandiri untuk membentuk hormon eritropoietin. ${ }^{6}$ Beberapa mekanisme lain yang dapat menyebabkan kadar hemoglobin normal pada pasien PGK ialah rangsangan dari insulin-like growth factor-1 (IGF-1) yang dihasilkan oleh hepatosit yang dapat merangsang pembentukan hormon eritropoietin. ${ }^{7}$

Kadar hemoglobin normal atau meningkat pada PGK dapat disebabkan karena mutasi gen reseptor eritropoietin (deletion mutation 1377-1411) atau oleh karena mutasi sinyal reseptor system eritropoietin (mutasi JAK2). Hal ini yang dikenal sebagai polisitemia pada pasien PGK, namun ciri khas dari kasus tersebut ialah ditemukan kadar eritropoietin rendah namun kadar hemoglobin meningkat. ${ }^{7}$ Sheqwara et $\mathrm{al}^{3}$ melaporkan suatu eritrositosis idiopatik pada pasien hemodialisis, yaitu pada kasus tersebut ditemukan kadar hemoglobin dan eritropoietin normal dengan menyingkirkan beberapa penyebab terjadinya eritrositosis pada pasien hemodialisis.

Elnaggar et $\mathrm{al}^{8}$ menghubungkan peningkatan kadar hemoglobin dan hematokrit pada pasien dengan hepatitis $\mathrm{C}$ yang menjalani hemodialisis, dan mendapatkan adanya hubungan bermakna. Hal ini dapat dijelaskan karena hati juga dapat menghasilkan eritropoietin. Dengan terdapatnya infeksi virus hepatitis, maka hati terangsang untuk membentuk eritropoietin. Hal inilah yang menyebabkan kadar ertiropoietin pada pasien dengan PGK yang disertai infeksi hepatitis tetap normal, demikian pula halnya dengan kadar hemoglobin dan hematokrit yang meningkat karena pengaruh rangsangan eritopoietin tersebut.

Laporan kasus oleh Sahin et al mendapatkan peningkatan kadar hemoglobin dan hematokrit pada pasien PGK dengan hepatitis $\mathrm{C}$ reaktif dan sebaliknya pada pasien hepatitis $\mathrm{C}$ yang negatif tidak ditemukan peningkatan kadar hemoglobin dan hematokrit. ${ }^{9}$ Pada kasus ini, seorang pasien PGK dengan rutin hemodialisis, dan pasien terinfeksi hepatitis $\mathrm{C}$ baru diketahui pada bulan Juni 2015. Hepatitis menyebabkan sel hati untuk beregenerasi sehingga memicu terbentuknya eritropoietin endogen yang dihasilkan oleh hepatosit yang baru. Hal ini yang menyebabkan kadar eritropoietin yang normal pada pasien ini $(16 \mathrm{mIU} / \mathrm{ml}$; nilai normal 2,6-18,5mIU/ml). Pasien tidak men- 
dapat terapi ESA selama 4 tahun namun pada pemeriksaan eritropoietin didapatkan hasil yang normal. Demikian pula dengan kadar hemoglobin yang normal sehingga pasien tidak pernah menjalani transfusi darah

Pada kasus ini diperlukan pemeriksaan lanjutan, seperti pemantauan berkala kadar hemoglobin, hematokrit, dan eritropoietin. Selain itu juga diperlukan pemeriksaan kadar paratiroid, penanda tumor, CT-scan abdomen untuk menyingkirkan kemungkinan lain untuk terjadinya peningkatan kadar eritropoietin pada pasien PGK yang menjalani hemodialisis.

\section{SIMPULAN}

Telah dilaporkan kasus seorang lakilaki 61 tahun dengan penyakit ginjal kronik hemodialisis dengan ko-infeksi hepatitis C dan kadar eritropoietin normal. Keadaan tersebut jarang ditemukan, dan tidak ada patofisologi yang pasti untuk menjelaskan penyebab keadaan tersebut. Mekanisme keadaan ini dikaitkan dengan infeksi hepatitis $\mathrm{C}$ yang merangsang regenerasi hepatosit, sehingga sel-sel tersebut menghasilkan ertiropoietin endogen, dengan hasil akhir terjadinya peningkatan hemoglobin.

\section{Konflik Kepentingan}

Penulis menyatakan tidak terdapat konflik kepentingan dalam studi ini.

\section{DAFTAR PUSTAKA}

1. Chalhoub S, Langston C, Eatroff A. Anemia of renal disease: what it is, what to do and what's new. Journal of Feline Medicine and Surgery. 2011;13(9):630-2.

2. Provatopoulou ST, Ziroyiannis PN. Clinical use of erythropoietin in chronic kidney disease: outcomes and future prospects. Hippokratia. 2011;15(2):109-15.

3. Sheqwara J, Alkhatib Y, Dabak V, Kuriakose P. Idiopathic erythrocytosis in dialysis patients: a case report and literature review. Am J Nephrol. 2013;37(4):3338.

4. Shalhoub RJ. Erythrocytosis in patients on longterm hemodialysis. Ann Intern Med. 1982;97(5):686.

5. Caramelo C, Navas S, Alberola ML, Bermejillo T, Reyero A, Carreño V. Evidence against transmission of hepatitis $\mathrm{C}$ virus through hemodialysis ultrafiltrate and peritoneal fluid. Nephron. 1994;66(4):470-3.

6. Lee DH, Min JH, Bae SB, Gil HW, Yang JO, Lee $\mathrm{EY}$, et al. Idiopathic erythrocytosis in a patient on chronic hemodialysis. Kidney Res Clin Pract. 2015;34(1):60-3.

7. Adeniyi M, Sun Y, Servilla KS, Hartshorne MF, Tzamaloukas AH. Spontaneous erythrocytosis in a patient on chronic hemodialysis. Hemodial Int. 2009;13 (Suppl1):S30-S3.

8. Elnaggar MN, Bichari WA, Elshinnawy $\mathrm{H}$. Effect of HCV infection versus HBV infection on the response to erythropoietin therapy in the treatment of anemia in prevalent haemodialysis patients. The Egyptian Journal of Hospital Medicine. 2018;70(1):92-6.

9. Saifan C, Kleiner, El-Charabaty E, Kleoner M, El-Sayegh S. Effect of hepatitis C virus infection on erythropoiesis in patients on hemodialysis. International Journal of Nephrology and Renovascular Disease. 2013;6:121. 